\title{
Accrual-Based Earnings Management: A Case Study in V4 Focusing on Mining And Quarrying Sector
}

\author{
Anna SIEKELOVA ${ }^{1 *}$, Jaroslav BELAS ${ }^{2}$, Ivana PODHORSKA ${ }^{3}$ and Pavol DURANA 4
}

\author{
Authors' affiliations and addresses: \\ ${ }^{1}$ University of Zilina, Faculty of Operation and \\ Economics of Transport and Communications, \\ Department of Economics, Univerzitna 8215/1, \\ 01026 Zilina, Slovakia \\ e-mail: anna.siekelova@fpedas.uniza.sk \\ ${ }^{2}$ University of Information Technology and \\ Management in Rzeszów, ul. Sucharskiego 2, 35- \\ 225 Rzeszów, Poland \\ e-mail: belas111@gmail.com
}

${ }^{3}$ University of Zilina, Faculty of Operation and Economics of Transport and Communications, Department of Economics, Univerzitna 8215/1, 01026 Zilina, Slovakia

e-mail: ivana.podhorska@fpedas.uniza.sk

${ }^{4}$ University of Zilina, Faculty of Operation and Economics of Transport and Communications, Department of Economics, Univerzitna 8215/1, 01026 Zilina, Slovakia

e-mail: pavol.durana@fpedas.uniza.sk

\section{*Correspondence:}

Anna Siekelova, University of Zilina, Faculty of Operation and Economics of Transport and Communications, Department of Economics, Univerzitna 8215/1, 01026 Zilina, Slovakia tel.: +421944280063

e-mail: anna.siekelova@fpedas.uniza.sk

Funding information:

The Slovak Research and Development Agency VEGA 1/0210/19

\section{Acknowledgement:}

This contribution is a partial outcome of the scientific project VEGA 1/0210/19 Research of innovative attributes of quantitative and qualitative fundaments of the opportunistic earnings modelling.

\section{How to cite this article:}

Siekelova, A., Belas, J., Podhorska, I. and Durana, P. (2020). Accrual-Based Earnings Management: A Case Study in V4 Focusing on Mining And Quarrying Sector. Acta Montanistica Slovaca, Volume 26 (1), 70-83

DOI:

https://doi.org/10.46544/AMS.v26i1.06

\begin{abstract}
The aim of the contribution is earnings management detection by using a model with the highest explanatory power, as well as verifying hypotheses about the existence of a statistically significant relationship between earnings management and country, as well as firm size within companies operating in the mining and quarrying sector in 2019 and 2018. Data were obtained from the Amadeus database. The sample contains 348 financial reports of companies from 2019 to 2017. Research is focused on V4 companies that have the sum of total assets higher than 2,000,000 EUR, as well as the sum of operating revenue is higher than 100,000 EUR. Three recommended models were used, namely the modified Jones model, Industry model, and Kothari model. The explanatory power of these models was tested by using several criteria. Based on the results, the modified Jones model was chosen for earnings management detection. According to the results, companies in the mining and quarrying sector in V4 use earnings management techniques to manage the profit. It is not possible to clearly determine in which direction they manage their profit more often. Different values were measured in the two observed periods. Based on the results, Czech and Slovak companies used earnings management techniques to increase their profit. On the other hand, Poland and Hungarian companies used earnings management techniques to decrease it. Very large as well as large companies used earnings management techniques to decrease their profit; medium-sized companies used earnings management techniques to increase it.
\end{abstract}

\section{Keywords}

Earnings, earnings management, accrual-based earnings management, mining, quarrying, V4. 


\section{Introduction}

The contribution deals with the phenomenon of earnings management focusing on the mining and quarrying sector within V4 countries. Earnings management is one of the most controversial issues in the field of accounting and finance. The basis of earnings management is profit. Reported financial results are a valuable source of information. Authors Li et al. (2019) state that a sovereign rating influence the assessment of the chances that a country will notbe able to pay its debt properly and on time. It can be perceived as a possibility of default. This perception is the same not only at the country level but also at the company level. Reported financial results indicate the level of success of a company. The informational value of reported financial results becomes questionable when we realize that business managers have not only the motivation but also the ability to use the earnings management practices to influence these results. Basically, there is no consensus within perceiving the earnings management issue. By using earnings management techniques, information asymmetry is reduced, and the relevance and reliability of financial statements can be improved. On the other hand, the opportunistic use of this freedom reduces the reliability of financial statements. It is necessary for users of financial statements to understand what earnings management represents and why it occurs. It is questionable whether users of financial statements are able to identify the existence of the earnings management techniques or they are misled by them. A potential inability of users of financial statements to identify the existence of the earnings management techniques raises the need to develop scientific methods for detecting and measuring earnings management.

The contribution is focused on the accrual-based earnings management issue. Foreign models for measuring earnings management were created in different economic conditions compared to the economies of the V4 countries (Gavurova et al., 2017). Also, each industry has its own specific characteristics, which these models usually do not take into account (Behun et al., 2018). The authors focus on carrying out research in a specific sector of the V4 countries, such as the mining and quarrying sector, and identifying the existence of the earnings management in this sector. The research describes the existence of earnings management, as well as the direction in which the reported financial results are managed by using the earnings management techniques.

The aim of the contribution is earnings management detection by using a model with the highest explanatory power, as well as verifying hypotheses about the existence of a statistically significant relationship between earnings management and country, as well as firm size within companies operating in the mining and quarrying sector in 2019 and 2018. Within the theoretical part of the contribution, the definition and motives of earnings management are defined. The importance of the issue of earnings management is confirmed by the brief results of the bibliometric analysis. Within the second part of the contribution, the aim is defined, as well as data and used methodology are described. Three widespread models for earnings management detection have been chosen, namely the modified Jones model, Industry model, and Kothari model. Within the methodological part, there are described criteria for the measurement of the explanatory power of these models. Hypotheses development is also a part of this section. The results are presented within the third part of the contribution. To analyze data, as well as testing hypotheses Excel and statistical add-on XLSTAT were used. All hypotheses were tested at the level of significance $\alpha=0.05$. The last part of the paper discusses how the authors focus on evaluating the achieved results and comparing them with existing studies.

\section{Theoretical Background}

The academic community focused on the relation between earnings management practices and the capital market. Researches dealt with the impact of the accounting choices connecting with earnings management initiatives on the capital market (El Diri, 2018; Kliestik et al., 2020, Poradova and Kollar, 2020; Belas et al., 2020). During the initial developing period, hypotheses known as mechanistic hypotheses were created. Based on these hypotheses, investors focused on the reported numbers, and they did not take into account differences in accounting choice and their impact on financial results. As a result, investors may be misled by using earnings management practices within accounting policy. Opinions in this field of study have evolved. Later hypotheses, also known as efficient market hypotheses, stated that investors, as well as stock prices, are influenced by all available information (Hsieh et al., 2018; Roychowdhury, 2006, Svabova et al., 2018).

Positive Accounting Theory, published in 1978 by authors Watts and Zimmermann, played a very important role in this field of study. The positive accounting theory is focused on the explanation and prediction of actual accounting practices. On the other hand, normative accounting theory deals with optimal accounting standards. Rational managers use appropriate accounting choices to influence financial outcomes in accordance with their interests. Earnings management practices can be defined as the way of using these appropriate accounting choices (Watts and Zimmermann, 1978).

Several different definitions of earnings management can be found. The literature review lists a variety of reasons why managers manipulate financial results (Kim et al., 2019, Cho et al., 2019, Poradova, 2020; Dvorsky et al., 2020a). Based on Healy, three types can be distinguished, namely motivations based on the theory of positive accounting, motivations related to the financial market, and motivations related to tax regulations. Author Gunny 
(2010) claims that companies that meet benchmarks have better operational performance in the future compared to companies that do not participate in earnings management initiatives. Investors rely on the views and forecasts of stock market analysts to build a portfolio of potentially successful companies. Meeting or exceeding analysts' forecasts seems important enough for companies to get involved in earnings management practices. Achieving analysts' expectations is important because companies that meet or exceed expectations gain higher returns. In this context, many authors said that market analysis is one of the most important factors which determines the financial condition of enterprises (Khan et al., 2020; Dvorsky et al., 2020b).

Rath and Sun (2008) state that earnings management practices take advantage of the application of accounting rules and creating financial statements that increase or balance financial results. The author also states that earnings management is a method of financial records manipulation to improve the company's financial situation image. Managers use earnings management practices to present balanced profits, as well as to smooth revenue fluctuations. One of the most popular ways to manipulate financial records is using an accounting policy that generates higher short-term income (Ball, 1972).

Authors Joshua Ronen and Varda Yaari summarized earnings management definitions. Within their publication, they state the classification of earnings management definition. Based on this classification, three ways of earnings management perceiving can be distinguished, namely white, grey, as well as black earnings management. Authors also claim beneficial (white) earnings management supports the transparency of financial reports. Black earnings management is defined as a pernicious type of earnings management that involves outright misrepresentation and fraud. Grey earnings management can be found among them. Grey earnings management is defined as a manipulation of reports within the boundaries of compliance with bright-line standards, which could be either opportunistic or efficiency-enhancing (Ronen and Yaari, 2008). Following Tab. 1 shows the alternative definitions of earnings management based on Ronen's and Yaari's study. Within their study, the overview of authors who identify with a given way of perceiving earnings management can also be seen. White earnings management practices were defined by authors Ronen, Patell, Demski, Wolfson, Suh, Beneish, Sadan, etc., grey earnings management practices were defined by authors Scott, Lys, Fields, Vincent etc. and black earnings management perceiving can be found within studies by Levitt, Healy, Yaari, Chtourou, Miller, Schipper, Tzur, Bahnson etc. (Ronen and Yaari, 2008).

As can be seen, the perceiving of earnings management issue within the authors are not the same even with respect to the period. Older, as well as newer studies, can be found among the studies tending to a specific perception of earnings management techniques. By author Ronen and Yaari, earnings management can be defined as a way of managerial decisions leading to a) not reporting the truth in the short-term, b) value-maximizing earnings.

The authors perceive earnings management techniques as beneficial - it signals long-term value; pernicious it conceals short- or long-term value; as well as neutral - it reveals the true short-term performance. Earnings management means managing financial results from taking production/investment actions before earnings are realized or making accounting choices that affect the financial results and their interpretation after the true earnings are realized (Ronen and Yaari, 2008).

Tab. 1. Earnings Management Perceiving Summarization.

\begin{tabular}{|c|c|c|}
\hline \multicolumn{3}{|c|}{ Earnings Management Perceiving } \\
\hline $\begin{array}{l}\text { "White" Earnings Management } \\
\text { "White" Earnings Management practices } \\
\text { take advantage of the flexibility in } \\
\text { accounting choices. The accounting choice } \\
\text { is influenced by manager's information on } \\
\text { financial results reported in the future. }\end{array}$ & $\begin{array}{l}\text { "Grey" Earnings Management } \\
\text { Within "Grey" Earnings Management } \\
\text { accounting choice depends on the effort to } \\
\text { gain the defined level of opportunistic or } \\
\text { economically efficiency. }\end{array}$ & $\begin{array}{l}\text { "Black" Earnings Management } \\
\text { The cause of the "Black" Earnings } \\
\text { Management practices using is a } \\
\text { misrepresentation of reported financial } \\
\text { results. }\end{array}$ \\
\hline
\end{tabular}

The authors Dechow and Skinner (2000) defined three types of reporting according to the GAAP related to the earnings management techniques. It can be seen in Tab. 2.

Tab. 2. Reporting types according to the GAAP.

\begin{tabular}{l|l}
\hline Reporting Types & Accounting Choices \\
\hline Conservative Accounting & $\begin{array}{l}\text { Overstatement of the sum of reserves and provisions. } \\
\text { Overstatement of the sum of assets write-offs, as well as } \\
\text { restructuring charges. } \\
\text { Neutral operations. } \\
\text { Understatement of the sum of provision for bad debts. } \\
\text { Asing aggressive manner to drawn down the sum of provisions or } \\
\text { reserves. }\end{array}$ \\
\hline
\end{tabular}

In the case of neutral accounting, reported earnings are the results of neutral operation. It means that earnings management techniques are not used. The authors also defined some ways for reported earnings manipulation that 
violet GAAP. Recording sales before they are realizable, as well as overstating inventory by recording fictitious inventory, are known. Some other methods of earnings management can be found in the available literature dealing with the issue. Tab. 3 shows chosen methods of how to manage earnings, as well as the overview of authors who deal with these methods within their studies based on studies by authors Dechow and Skinner (2000), Ronen and Yaari (2008) and Siregar and Utama (2008).

Tab. 3. Widespread accounting methods indicate earnings management.

\begin{tabular}{|c|c|}
\hline Method & Author (Year of Study) \\
\hline \multirow{2}{*}{ The inventory valuation based on FIFO vs LIFO method } & Hughes, Swartz and Fellingham (1988) \\
\hline & Neil, Pourciau and Schaefer (1995) \\
\hline \multirow{2}{*}{ Accounting choice within depreciation policy } & Neil, Pourciau and Schaefer (1995) \\
\hline & Bishop and Eccher (2000) \\
\hline Accounting choice within revenue recognition policy & Bowen, Davis and Rajgopal (2002) \\
\hline \multirow{3}{*}{$\begin{array}{l}\text { Using the full cost method vs the successful effort method within } \\
\text { the oil and gas industry }\end{array}$} & Malmquist (1990) \\
\hline & Zeff (1993) \\
\hline & Aboody (1996) \\
\hline \multirow{4}{*}{ Timing for using a new standard } & Ali and Kumar (1994) \\
\hline & Lehavy and Revsine (1994) \\
\hline & Smith and Rezaee (1995) \\
\hline & Amir and Livnat (1996) \\
\hline Not implementing a new standard on the grounds of immateriality & Gilkeson and Stenger (1999) \\
\hline \multirow{2}{*}{ The transparency of the presentation managing } & Smith and Emshwiller (2003) \\
\hline & Reidl and Srinivasan (2006) \\
\hline Judgement call in the case when GAAP requires estimates & Bishop and Eccher (2000) \\
\hline \multirow{4}{*}{$\begin{array}{l}\text { A definition of items as above or below the line of operating } \\
\text { earnings in the case when persistent earnings have to be separated } \\
\text { from transitory earnings }\end{array}$} & Godfrey and Jones (1999) \\
\hline & Dye (2002) \\
\hline & Lin, Radhakrishnan and Su (2006) \\
\hline & McVay (2006) \\
\hline Transaction structuring to gain required financial results & Marquardt and Wiedman (2005) \\
\hline \multirow{2}{*}{ Revenues and expanses timing } & Bartov (1993) \\
\hline & Muller (1999) \\
\hline \multirow{4}{*}{$\begin{array}{l}\text { Increasing research and development expenditures, as well as } \\
\text { influencing administrative and selling expenses }\end{array}$} & Lin, Radhakrishnan and Su (2006) \\
\hline & Roychowdhurry (2006) \\
\hline & Bens and Monahan (2005) \\
\hline & Singer (2007) \\
\hline $\begin{array}{l}\text { The informativeness of reported earnings managing using various } \\
\text { means (reporting comprehensive income on the statement of equity } \\
\text { rather than on performance statement to present "pro forma } \\
\text { earnings") }\end{array}$ & Lee, Petroni and Shen (2006) \\
\hline
\end{tabular}

There are some motives of earnings management initiatives:

- $\quad$ avoiding the risk of stock price decreasing if achieved earnings are lower than expected (Valaskova et al., 2020);

- reporting financial results at the level for the maximum possible premium (Lee and Choi, 2002);

- $\quad$ reducing profit volatility due to one-off items (Viczeova and Kascakova, 2017);

- creating the best picture of profit to maximize the selling price of stocks if the company is considering an IPO (Sosnowski, 2018);

- new management efforts to show lower earnings in the first periods after accession in order to attribute such a situation as a result of old management decisions (Mulford and Comiskey, 2005).

One group of motives for using earnings management initiatives using is also known as third-party motives. The basis of this group of motives is the existence of the third parties who need financial information within the process of decision-making focused on entering into business transactions with the company. The relations of the company with the third parties influence its earnings management behaviour to be able to maintain its future interests with them (Siregar and Utama, 2008). In this context, Metzker and Streimikis (2020) or Rozsa et al. (2019) state that the key is the position of the company's owners, special for the SME segment.

Even today, there are still many studies focused on the issue of earnings management. The importance of the issue of earnings management can also be confirmed by the brief results of the bibliometric analysis presented below (Fig. 1). 


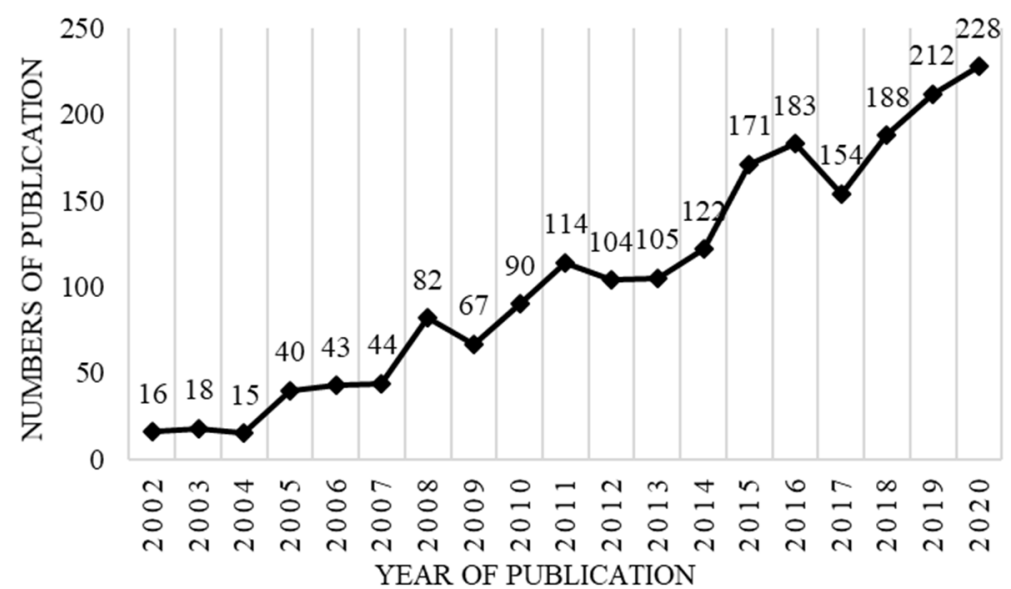

Fig. 1. Numbers of articles dealing with earnings management issue published within the Web of Science Core Collection database.

Fig. 1 shows the numbers of published articles dealing with earnings management within the Web of Science Core Collection database from 2002 to 2020. The Web of Science Core Collection database is provided by the Web of Science website currently maintained by Clarivate Analytics. The Web of Science Core Collection database is a widespread well-known database within the academic community. It consists of six online databases and provides access to the world's leading scholarly journals, books, and proceedings in the sciences, social sciences, and arts and humanities and navigates the full citation network. As it can be seen, the number of articles dealing with the earnings management issue has been increasing. On this basis, it can be seen that interest in this field of study exists. In the last two years, 440 publications dealing with earnings management have been published. A total of 1996 publications were published during the reviewed period. The database contains data since 1900. It can be said, the database also provides older data, but the interest in this field of study has been increasing since 2002. From 1900 to 2002, fewer publications dealing with this topic were published compared to the period under review (2002 - 2020). By the day of the bibliometric analysis, 25 articles on the topic of earnings management were published in the database in 2021.

Earnings management topic can be found within several fields of study. Almost $91 \%$ of contributions were published within the research area: Business Economic. Almost 20\% of contributions were published within the research areas: Social Sciences Other Topics, Public Administration, Computer Science, Operations Research Management Science, Engineering, Science Technology Other Topics, Education Educational Research, Environmental Sciences Ecology. Contributions can be included in more than one research area.

Network visualization of keyword contribution dealing with earnings management issue was realized as a part of bibliometric analysis. Keyword science map was created by using VOSviewer software (Nyons, 2001). On the basis of the keyword map results, publications focused on earnings management contain keywords: accruals, ownership, corporate, governance, audit quality, real activities, valuation, market, and so on.

Foreign and domestic authors deal with the issue. Most publications have been published in the USA (620), People R China (447), Taiwan (126), or Australia (110). Most publications within Europe have been published in England (107), Spain (68), Italy (48), or France (43). Most publications within V4 countries have been published in Poland (15) and Slovakia (15). Two publications have been published in the Czech Republic, and one publication dealing with earnings management issue has been published in Hungary. The University of Zilina is one of the leading places where the topic of earnings management is published, thanks to the authors Valaskova (6), Durana (5), Kliestik (4), and Siekelova (3).

\section{Aim, Methodology and Data}

The aim of the contribution is earnings management detection by using a model with the highest explanatory power, as well as verifying hypotheses about the existence of a statistically significant relationship between earnings management and country, as well as firm size within companies operating in the mining and quarrying sector in 2019 and 2018.

Data were obtained from the Amadeus database. It is a widely known database containing financial information about companies across Europe. The database is provided by Bureau van Dijk, a Moody's Analytics company. The sample contains 348 companies. Tab. 4 shows the used search strategy. 
Tab. 4. Search strategy.

\begin{tabular}{|c|c|c|c|}
\hline Step & Used Search Rule & $\begin{array}{l}\text { Number of Enterprises Not } \\
\text { Meeting the Search Rules }\end{array}$ & Search Results \\
\hline 1 & $\begin{array}{l}\text { All active companies from } \\
2017-2019\end{array}$ & 0 & $21,564,265$ \\
\hline 2 & $\begin{array}{l}\text { Country: Czech Republic, } \\
\text { Slovakia, Poland and Hungary }\end{array}$ & $18,621,241$ & $2,943,024$ \\
\hline 3 & $\begin{array}{l}\text { Total assets (th EUR) } \min = \\
2,000 ; \text { exclusion of companies } \\
\text { with no recent financial data } \\
\text { Operating revenues (th EUR) }\end{array}$ & $2,896,111$ & 46,913 \\
\hline 4 & $\begin{array}{l}\min =100 ; \text { exclusion of } \\
\text { companies with no recent } \\
\text { financial data }\end{array}$ & 3,221 & 43,692 \\
\hline 5 & $\begin{array}{l}\text { Mining and quarring sector } \\
\text { Exclusion of companies with }\end{array}$ & 43,184 & 508 \\
\hline 6 & $\begin{array}{l}\text { no recent financial data for } \\
\text { variables calculation }\end{array}$ & 61 & 447 \\
\hline 7 & Outliers detection & 99 & 348 \\
\hline \multicolumn{3}{|c|}{ Sample size } & 348 \\
\hline
\end{tabular}

As it can be seen, seven search rules were used. Research is focused on V4 companies that have the sum of total assets higher than 2,000,000 EUR, as well as the sum of operating revenue is higher than 100,000 EUR. According to the NACE classification, companies are included in the mining and quarrying sector. In the $6^{\text {th }}$ step, companies without relevant data for variables calculation were excluded. In the final step, the Interquartile range method (IQR) was used to identify outliers. Borders set by the author of this method - Turkey are as follow.

$$
I Q R(\text { the interquartile range })=Q_{3}(\text { the upper quartile })-Q_{1}(\text { the lower quartile })
$$

An outlier can be defined as a value below $Q_{1}-\mathbf{1 . 5}(I Q R)$ or above $Q_{3}+\mathbf{1 . 5}(I Q R)$. Based on the outliers detection, 99 companies were excluded. The final size of the companies is 348 . Tab. 5 shows the detailed specification of the final sample.

Tab. 5. Sample specification.

\begin{tabular}{l|l|l}
\hline Criterion & Classification & Number of Companies \\
\hline \multirow{4}{*}{ Country } & Slovakia & 72 \\
& Czech Republic & 120 \\
& Poland & 144 \\
& Hungary & 12 \\
\hline & 0510 & 18 \\
& 0520 & 24 \\
National Industry Code & 0811 & 84 \\
& 0812 & 174 \\
& 0891 & 6 \\
& 0892 & 6 \\
& 0893 & 6 \\
& 0899 & 12 \\
& 0910 & 6 \\
& 0990 & 12 \\
\hline
\end{tabular}

Material and methods part contains a description of using methods description. It is necessary to define basic theoretical terms.

Accruals are defined as a difference between net income and cash flows. The Sum of total accruals contains a non-discretionary component or non-discretionary accruals (NDA), as well as a discretionary component or discretionary accruals (DA). DA corresponds to adjustments made to the cash flow, selected by managers focused on their interests in terms of earnings. NDA corresponds to adjustments made to the cash flow, resulting from the application of accounting standards in a rational manner and considering the evolving economic conditions of the company (Mendesa et al., 2012; Sosnowski, 2018).

Contribution deals with earnings management problems focused on the mining and quarrying sector in V4. Most of the available models of earnings management were created abroad. As a result, their explanatory power may be lower when used in V4 countries. There are three models used for earnings management initiatives calculation within the publication, as was mentioned above. The authors also focused on the explanatory power of these models before using them for earnings management detection. Tab. 6 shows used methods proposed by the literature for the assessment of the explanatory power of earnings management models. 
Tab. 6. Selected methods for the assessment of explanatory power of earnings management models.

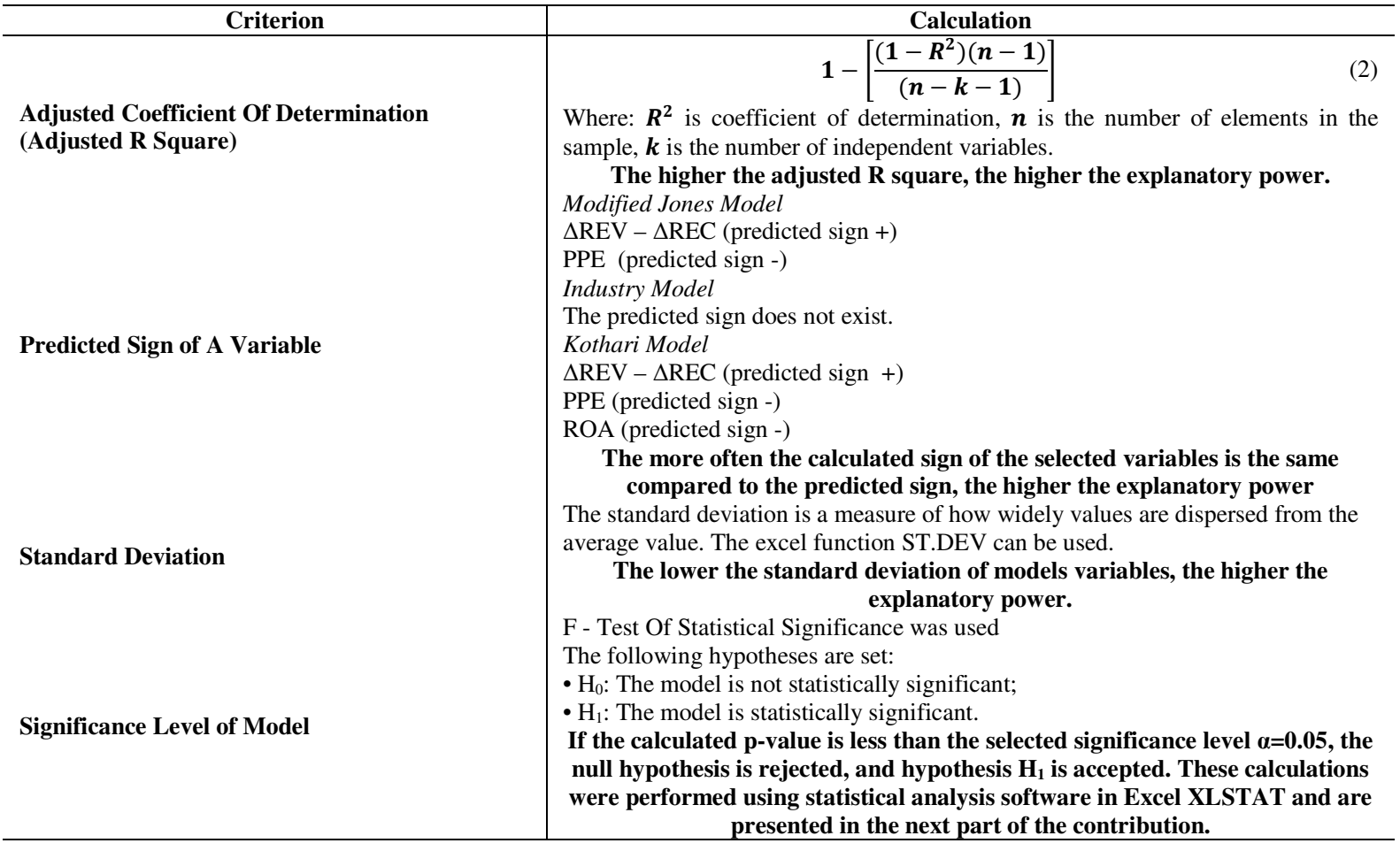

There are several methods for earnings management determination. Determination of accrual-based earnings management is based on using earnings management models. Within researches, considerable attention is paid to the earnings management models. Despite that, a uniform model for earnings management determination does not exist. Authors focused on the most known and widespread used models, namely the modified Jones model, Industry model by Dechow and Sloan, Kothari model. There are formulas used for the calculation of selected models.

Modified

Jones Model

$$
\frac{T A_{i t}}{A_{i t-1}}=\alpha_{0} \frac{1}{A_{i t-1}}+\alpha_{1} \frac{\Delta R E V_{i t}-\Delta R E C_{i t}}{A_{i t-1}}+\alpha_{2} \frac{P P E_{i t}}{A_{i t-1}}+\varepsilon_{i t}
$$

Industry

model

$$
N D A_{t}=\gamma_{1}+\gamma_{2} * \operatorname{median}\left(T A_{t}\right)
$$

Kothari model $\frac{N D A_{i t}}{A_{i t-1}}=\frac{T A_{i t}}{A_{i t-1}}=a_{0} \frac{1}{A_{i t-1}}+\alpha_{1} \frac{\Delta R E V_{i t}-\Delta R E C_{i t}}{A_{i t-1}}+\alpha_{2} \frac{P P E_{i t}}{A_{i t-1}}+\alpha_{3} \frac{R O A_{i t-1}}{A_{i t-1}}$

Where:
$T A_{i t}$
$A_{i t-1}$
$\triangle R E V_{i t}$
$\triangle R E C_{i t}$
$P P E_{i t}$
$\varepsilon_{i t}$
$\gamma_{1}$
$\gamma_{2}$
median $\left(T A_{t}\right)$
$N D A_{i t}$
$R O A_{i t-1}$

the sum of total accruals in year $t$;

the sum of assets in year $t-1$;

the change in revenues between years $t$ and $t-1$;

the change in receivables between years $t$ and $t-1$.

the sum of the property, plant $\&$ equipment in year $t$;

statistical error;

industry-specific parameter;

industry-specific parameter;

the median of total accruals within the industry in year $t$;

the sum of non-discretionary accruals in year $t$;

return on assets in year $t-1$.

There are two approaches to total accruals calculation. The following formula is used for total accruals calculation. It is also known as the balance sheet approach (Hoglund, 2012). 


$$
T A=\Delta C A-\Delta C L-\Delta C a s h+\Delta S T D-D e p
$$

Where:

$T A$

$\triangle C A$

$\triangle C L$

$\triangle$ Cash

$\triangle S T D$

Dep

the sum of total accruals;

the change in current assets;

the change in current liabilities;

the change in cash and cash equivalents;

the change in the current maturities of long-term debt and other short-term debt included in current liabilities;

Based on the explanatory power, the appropriate model for earnings management practices detection within selected mining or quarrying companies were chosen. Using the selected model, the presence of earnings management practices within a selected set of companies was tested.

Based on the previous results, the following hypotheses were set in accordance with the research questions:

Does a relationship between the level of earnings management initiatives and country, as well as company size exist? Two pairs of hypotheses were set:

$\mathrm{H}_{0} \quad$ There is no statistically significant connection between the level of earnings management initiatives and country of business operations.

$\mathrm{H}_{1} \quad$ There is a statistically significant connection between the level of earnings management initiatives and country of business operations.

$\mathrm{H}_{0} \quad$ There is no statistically significant connection between the level of earnings management initiatives and company size determined by the level of assets.

$\mathrm{H}_{1} \quad$ There is a statistically significant connection between the level of earnings management initiatives and company-sized.

The one-way analysis of variance (ANOVA) was used to test the hypotheses. Analysis of variance is used to determine if statistically significant differences between the means of two or more independent groups exist or not. The $p-$ value calculated by using the software was used as a decision rule. If the calculated $p-v a l u e$ is less than 0.05 , the difference between the means in the sample is too large to be random; we reject $\mathrm{H}_{0}$ and do not reject $\mathrm{H}_{1}$ and vice versa.

To analyze data, as well as testing hypotheses Excel and statistical add-on XLSTAT were used. All hypotheses were tested at the level of significance $\alpha=0.05$. All results are presented below.

\section{Results}

In the beginning, the variables of the selected models were calculated. Tables 7-10 show the model results of five selected companies. The sum of total accruals was calculated based on formula 6. Variables were calculated according to the selected models (formulas 3-5).

Tab. 7. Model results of total accruals calculation with descriptive statistics indicators.

\begin{tabular}{|c|c|c|c|c|c|c|c|c|c|}
\hline $\begin{array}{l}\text { The sum of } \\
\text { total } \\
\text { accruals in } \\
\text { the year } \\
2019^{*}\end{array}$ & $\begin{array}{l}\text { The sum of } \\
\text { total } \\
\text { accruals in } \\
\text { the year } \\
2018^{*}\end{array}$ & $\begin{array}{c}\text { Average } \\
\text { (total } \\
\text { accruals } \\
2019)^{*}\end{array}$ & $\begin{array}{c}\begin{array}{c}\text { Average } \\
\text { (total }\end{array} \\
\text { accruals } \\
2018)^{*}\end{array}$ & $\begin{array}{c}\text { Median } \\
\text { (total } \\
\text { accruals } \\
2019)^{*}\end{array}$ & $\begin{array}{c}\text { Median } \\
\text { (total } \\
\text { accruals } \\
2018)^{*}\end{array}$ & $\begin{array}{c}\text { Standard } \\
\text { deviation } \\
\text { (total } \\
\text { accruals } \\
2019)^{*}\end{array}$ & $\begin{array}{c}\text { Standard } \\
\text { deviation } \\
\text { (total } \\
\text { accruals } \\
2018)^{*}\end{array}$ & \begin{tabular}{|c|} 
Coefficient \\
of \\
variation \\
(total \\
accruals \\
2019 ) \\
\end{tabular} & $\begin{array}{l}\text { Coefficient } \\
\text { of } \\
\text { variation } \\
\text { (total } \\
\text { accruals } \\
2018 \text { ) } \\
\end{array}$ \\
\hline $\begin{array}{l}-40,411 \\
-61,472 \\
-18,108 \\
-1,142 \\
-2,992\end{array}$ & $\begin{array}{c}-18,297 \\
-63,338 \\
-11,743 \\
-995 \\
-3,561\end{array}$ & $-2,385$ & $-2,005$ & -542 & -397 & 8,082 & 7,282 & -0.2950 & -0.2753 \\
\hline
\end{tabular}

* calculated values are in thousands of EUR.

Tab. 8. Calculated variables - Modified Jones model.

\begin{tabular}{c|c|c|c|c|c|c|c}
\hline \multicolumn{4}{c|}{ Modified Jones model variables (2019) } & \multicolumn{3}{c}{ Modified Jones model variables (2018) } \\
\hline$\frac{T A_{i t}}{A_{i t-1}}$ & $\frac{1}{A_{i t-1}}$ & $\frac{\Delta R E V_{i t}-\Delta R E C_{i t}}{A_{i t-1}}$ & $\frac{P P E_{i t}}{A_{i t-1}}$ & $\frac{T A_{i t}}{A_{i t-1}}$ & $\frac{1}{A_{i t-1}}$ & $\frac{\Delta R E V_{i t}-\Delta R E C_{i t}}{A_{i t-1}}$ & $\frac{P P E_{i t}}{A_{i t-1}}$ \\
\hline-0.066241 & 0.000002 & 0.000019 & 0.489208 & -0.029998 & 0.000002 & 0.021613 \\
-0.167229 & 0.000003 & 0.204506 & 0.490237 & -0.148508 & 0.000002 & 0.001305 \\
-0.102333 & 0.000006 & -0.022712 & 0.399642 & -0.047687 & 0.000004 & -0.514905 & 0.523409 \\
\end{tabular}




\begin{tabular}{l|l|l|l|l|l|l|l}
\hline & & & & & & \\
-0.025871 & 0.000023 & -0.007798 & 0.677454 & -0.023350 & 0.000023 & 0.047366 & 0.711113 \\
-0.051910 & 0.000017 & 0.010214 & 0.584024 & -0.061843 & 0.000017 & 0.040226 & 0.601735 \\
\hline
\end{tabular}

Tab. 9. Calculated variables - Kothari model.

\begin{tabular}{|c|c|c|c|c|c|c|c|c|c|}
\hline \multicolumn{5}{|c|}{ Kothari model variables (2019) } & \multicolumn{5}{|c|}{ Kothari Jones model variables (2018) } \\
\hline$\frac{T A_{i t}}{A_{i t-1}}$ & $\frac{1}{A_{i t-1}}$ & $\frac{\Delta R E V_{i t}-\Delta R E C_{i t}}{A_{i t-1}}$ & $\frac{P P E_{i t}}{A_{i t-1}}$ & $\frac{R O A_{i t-1}}{A_{i t-1}}$ & $\frac{T A_{i t}}{A_{i t-1}}$ & $\frac{1}{A_{i t-1}}$ & $\frac{\Delta R E V_{i t}-\Delta R E C_{i t}}{A_{i t-1}}$ & $\frac{P P E_{i t}}{A_{i t-1}}$ & $\frac{R O A_{i t-1}}{A_{i t-1}}$ \\
\hline-0.066241 & 0.000002 & 0.000019 & 0.489208 & 0,00000001 & -0.029998 & 0.000002 & 0.021613 & 0.521339 & $-0,0000080$ \\
\hline-0.167229 & 0.000003 & 0.204506 & 0.490237 & 0,00000001 & -0.148508 & 0.000002 & 0.001305 & 0.523409 & $-0,0000004$ \\
\hline-0.102333 & 0.000006 & -0.022712 & 0.399642 & 0,00000003 & -0.047687 & 0.000004 & -0.514905 & 0.359252 & $-0,0000065$ \\
\hline-0.025871 & 0.000023 & -0.007798 & 0.677454 & 0,00000018 & -0.023350 & 0.000023 & 0.047366 & 0.711113 & 0,0000232 \\
\hline-0.051910 & 0.000017 & 0.010214 & 0.584024 & 0,00000022 & -0.061843 & 0.000017 & 0.040226 & 0.601735 & $-0,0000195$ \\
\hline
\end{tabular}

Tab.10. Calculated variables - Industry model.

\begin{tabular}{c|c|c|c|c|c}
\hline \multicolumn{3}{c|}{ Industry model variables (2019) } & \multicolumn{3}{|c}{ Industry model variables (2018) } \\
\hline$\frac{T A_{i t}}{A_{i t-1}}$ & $\frac{1}{A_{i t-1}}$ & Median (total accruals 2019)* & $\frac{T A_{i t}}{A_{i t-1}}$ & $\frac{1}{A_{i t-1}}$ & Median (total accruals 2018)* \\
\hline-0.066241 & 0.000002 & & -0.029998 & 0.000002 & \\
-0.167229 & 0.000003 & & -0.148508 & 0.000002 & \\
-0.102333 & 0.000006 & -542 & -0.047687 & 0.000004 & \\
-0.025871 & 0.000023 & & -0.023350 & 0.000023 & \\
-0.051910 & 0.000017 & & -0.061843 & 0.000017 & \\
\hline
\end{tabular}

* calculated values are in thousands of EUR.

Table 11 shows the results of descriptive statistics of calculated variables for observed period $2019-2018$.

Tab.11. Descriptive statistics of selected variables.

\begin{tabular}{|c|c|c|c|c|c|c|c|c|c|c|}
\hline \multirow{2}{*}{$\begin{array}{c}\text { Descript. } \\
\text { Statistics } \\
\text { of Selected } \\
\text { Variables }\end{array}$} & \multicolumn{5}{|c|}{2019} & \multicolumn{5}{|c|}{2018} \\
\hline & $\frac{T A_{i t}}{A_{i t-1}}$ & $\frac{1}{A_{i t-1}}$ & $\frac{\Delta R E V_{i t}-\Delta R E C_{i t}}{A_{i t-1}}$ & $\frac{P P E_{i t}}{A_{i t-1}}$ & $\frac{R O A_{i t-1}}{A_{i t-1}}$ & $\frac{T A_{i t}}{A_{i t-1}}$ & $\frac{1}{A_{i t-1}}$ & $\frac{\Delta R E V_{i t}-\Delta R E C_{i t}}{A_{i t-1}}$ & $\frac{P P E_{i t}}{A_{i t-1}}$ & $\frac{R O A_{i t-1}}{A_{i t-1}}$ \\
\hline Mean & -0.06469 & 00016 & 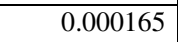 & .545166 & 1 & 0.05588 & .000166 & 66 & .000166 & 0.000037 \\
\hline Err & 189 & 0008 & 8 & 180 & 0 & 36 & 88 & 8 & 00008 & 0. \\
\hline Mec & -0.07176 & 0.000117 & 0.000117 & 0.519015 & 0.00001 & -0.06209 & 0.000120 & 0.000120 & 0.000120 & 0.000017 \\
\hline $\begin{array}{l}\text { Stan } \\
\text { Devi }\end{array}$ & 0.09126 & .000150 & 0.000150 & 0.221959 & 0.00002 & 0.10928 & 0.000143 & 0.000143 & 0.000143 & 0.000727 \\
\hline $\begin{array}{l}\text { Sample } \\
\text { Variance }\end{array}$ & 3 & 0 & 0.000000 & 6 & 0 & 0.01194 & 0.000 & 0.000000 & 0.000000 & 0.000001 \\
\hline & & & & & & & & & & 737 \\
\hline & & & & & & & & & & 422 \\
\hline & & & & & & & & & & \\
\hline & & & & & & & & & & -0.0 \\
\hline Ma & 8666 & 00717 & 0.000717 & 1.218090 & 0.00013 & 0.48490 & .000652 & 0.000652 & 0.000658 & 0.003258 \\
\hline Count & 348 & 348 & 348 & 348 & 348 & 348 & 348 & 348 & 348 & 348 \\
\hline
\end{tabular}

Based on recommended criteria described in Tab. 6, the explanatory power of selected models was tested. As it can be seen, all tested models are statistically significant. The explanatory power determined by the adjusted $\mathrm{R}$ square is different. The explanatory power of the industry model is the lowest. The explanatory power of the modified Jones model and Kothari model is comparable. The sign of the predicted variable is in all cases identical with the calculated sign of the modified Jones model. Based on the results, the authors decided to use the modified Jones model for earnings management detection.

Tab. 12 shows only the results of the models' explanatory power for 2019. The interpretation of the results is the same in 2018. 
Tab.12. Explanatory power of selected models 2019.

\begin{tabular}{|c|c|c|c|c|c|c|c|c|}
\hline Criterion & \multicolumn{3}{|c|}{ Modified Jones model } & \multicolumn{3}{|c|}{ Kothari model } & \multicolumn{2}{|c|}{ Industry model } \\
\hline $\begin{array}{l}\text { Adjusted R } \\
\text { Square }\end{array}$ & \multicolumn{3}{|c|}{0.44} & \multicolumn{3}{|c|}{0,48} & \multicolumn{2}{|c|}{0,33} \\
\hline \multirow[b]{2}{*}{$\begin{array}{l}\text { Predicted } \\
\quad \text { Sign }\end{array}$} & Variables & Predicted & Calculated & Variables & Predicted & Calculated & \multirow{2}{*}{\multicolumn{2}{|c|}{ NO }} \\
\hline & $\begin{array}{c}\Delta R E V_{i t}-\Delta R E C_{i t} \\
P P E_{i t}\end{array}$ & $\begin{array}{l}+ \\
-\end{array}$ & $\begin{array}{l}+ \\
-\end{array}$ & $\begin{array}{c}\Delta R E V_{i t}-\Delta R E C_{i t} \\
P P E_{i t} \\
R O A_{i t-1}\end{array}$ & $\begin{array}{l}+ \\
- \\
-\end{array}$ & $\begin{array}{l}+ \\
- \\
+\end{array}$ & & \\
\hline \multirow{5}{*}{$\begin{array}{l}\text { Standard } \\
\text { Deviation }\end{array}$} & Variables & \multicolumn{2}{|c|}{ Calculated Value } & Variables & \multicolumn{2}{|c|}{ Calculated Values } & Variables & $\begin{array}{c}\text { Calculated } \\
\text { Value }\end{array}$ \\
\hline & $\frac{1}{A_{i t-1}}$ & \multicolumn{2}{|c|}{0.0001497} & $\frac{1}{A_{i t-1}}$ & \multicolumn{2}{|c|}{0.0001497} & & \multirow{4}{*}{0.0001497} \\
\hline & $\frac{\Delta R E V_{i t}-\Delta R E C_{i t}}{A_{i t-1}}$ & \multicolumn{2}{|c|}{0.0001497} & $\frac{\Delta R E V_{i t}-\Delta R E C_{i t}}{A_{i t-1}}$ & \multicolumn{2}{|c|}{0.0001497} & 1 & \\
\hline & & & & $\frac{P P E_{i t}}{A_{i t-1}}$ & 0.22 & 9587 & $\overline{A_{i t-1}}$ & \\
\hline & $\frac{P P E_{i t}}{A_{i t-1}}$ & \multicolumn{2}{|c|}{0.2219587} & $\frac{\mathrm{ROA}_{\mathrm{it}-1}}{\mathrm{~A}_{\mathrm{it}-1}}$ & \multicolumn{2}{|c|}{0.000023} & & \\
\hline $\begin{array}{l}\text { Significance } \\
\text { Level of the } \\
\text { Model } \\
\end{array}$ & \multicolumn{3}{|c|}{$\begin{array}{l}H_{1} \text { is accepted } \\
\text { The model is statistically significant. }\end{array}$} & \multicolumn{3}{|c|}{$\begin{array}{l}\qquad \mathrm{H}_{1} \text { is accepted } \\
\text { The model is statistically significant. }\end{array}$} & \multicolumn{2}{|c|}{$\begin{array}{c}\mathrm{H}_{1} \text { is accepted } \\
\text { The model is } \\
\text { statistically significant. }\end{array}$} \\
\hline
\end{tabular}

Based on the results of the modified Jones model, the sum of discretionary accruals, as well as the sum of non-discretionary accruals, were calculated. Earnings management detection is based on the estimation of the sum of discretionary accruals. According to the modified Jones model, the sum of the discretionary accruals can be set as residuals of calculated regression. The value of discretionary accruals determines if a company uses earnings management practices to increase or decrease profit (Pham et al., 2019). If the value of discretionary accruals is higher than 0 , the company used accrual-based earnings management to increase profit and vice versa. Within the mining and quarrying sector in V4 countries, the results are as follow:

- almost 45\% (156 out of 348) companies used earnings management practices to increase their profit in 2019 ;

- the remaining almost $66 \%$ (228 out of 348) companies used earnings management practices to decrease their profit in 2019;

- almost 52\% (180 out of 348) companies used earnings management practices to increase their profit in 2018

- the remaining almost $48 \%$ (168 out of 348) companies used earnings management practices to decrease their profit in 2018;

- the average sum of the discretionary accruals was -0.0005301 , the median was -0.0035237 , and the standard deviation was 0.0830728 in 2019 ;

- the average sum of the discretionary accruals was 1.231402 , the median was 0,001016 , and the standard deviation was 0.104117 in 2018.

The last part of the research was focused on the hypotheses verification. Hypotheses were verified using the one-way analysis of variance described in the methodology part. Two pairs of hypotheses were set:

$\mathrm{H}_{0} \quad$ There is no statistically significant connection between the level of earnings management initiatives and country of business operations.

$\mathrm{H}_{1} \quad$ There is a statistically significant connection between the level of earnings management initiatives and country of business operations.

$\mathrm{H}_{0} \quad$ There is no statistically significant connection between the level of earnings management initiatives and company size.

$\mathrm{H}_{1} \quad$ There is a statistically significant connection between the level of earnings management initiatives and company size.

The calculated $p$-value was less than 0.05 , differences between the means in the sample are too large to be random, we reject $\mathrm{H}_{0}$ and accept $\mathrm{H}_{1}$. It can be stated that: 
- There is a statistically significant connection between the level of earnings management initiatives and country of business operations, as well as there is a statistically significant connection between the level of earnings management initiatives and company size in the year 2019.

- There is a statistically significant connection between the level of earnings management initiatives and country of business operations, as well as there is a statistically significant connection between the level of earnings management initiatives and company size in the year 2018.

These statements can be confirmed by the results summarized within Tab. 13-16.

Tab. 13. ANOVA results - summary statistic; groups: the sum of discretionary accruals and firm size $(2019,2018)$

\begin{tabular}{l|cc|c|c|c|c|c|c}
\hline \multicolumn{1}{c|}{ Groups } & \multicolumn{2}{c|}{ Count } & \multicolumn{2}{c|}{ Sum } & \multicolumn{3}{c|}{ Average } & \multicolumn{2}{c}{ Variance } \\
\cline { 2 - 8 } & 2019 & 2018 & 2019 & 2018 & 2019 & 2018 & 2019 & 2018 \\
\hline The Sum of Discretionary Accruals & 348 & 348 & -0.18446 & 1.23140 & -0.00053 & 0.00359 & 0.00690 & 0.01085 \\
Firm Size & 348 & 348 & 540 & 540 & 1.55172 & 1.55172 & 0,31720 & 0.31720 \\
\hline
\end{tabular}

Tab. 14. ANOVA results - summary statistic; groups: the sum of discretionary accruals and country $(2019,2018)$

\begin{tabular}{l|cc|c|c|c|c|c|c}
\hline \multicolumn{1}{c|}{ Groups } & \multicolumn{2}{c|}{ Count } & \multicolumn{2}{c|}{ Sum } & \multicolumn{3}{c|}{ Average } & \multicolumn{2}{c}{ Variance } \\
\cline { 2 - 8 } & 2019 & 2018 & 2019 & 2018 & 2019 & 2018 & 2019 & 2018 \\
\hline The Sum of Discretionary Accruals & 348 & 348 & -0.18446 & 1.23140 & -0.00053 & 0.00359 & 0.00690 & 0.01085 \\
Firm Size & 348 & 348 & 865 & 864 & 2.48563 & 2.48276 & 1.36291 & 1.35705 \\
\hline
\end{tabular}

Tab. 15. ANOVA results; groups: the sum of discretionary accruals and firm size $(2019,2018)$

\begin{tabular}{|c|c|c|c|c|c|c|c|c|c|c|c|c|}
\hline \multirow{2}{*}{$\begin{array}{l}\text { Source of } \\
\text { Variation }\end{array}$} & \multicolumn{2}{|c|}{ SS } & \multicolumn{2}{|c|}{ df } & \multicolumn{2}{|c|}{ MS } & \multicolumn{2}{|c|}{$\mathrm{F}$} & \multicolumn{2}{|c|}{ P-value } & \multicolumn{2}{|c|}{ F crit. } \\
\hline & 2019 & 2018 & 2019 & 2018 & 2019 & 2018 & 2019 & 2018 & 2019 & 2018 & 2019 & 2018 \\
\hline $\begin{array}{l}\text { Between } \\
\text { Groups }\end{array}$ & 419.25 & 417.06 & 1 & 1 & 419.25 & 417.06 & $2,587.15$ & $2,542.61$ & $\begin{array}{c}2.6488 E- \\
236\end{array}$ & $\begin{array}{c}3.0465 \mathrm{E}- \\
234\end{array}$ & 3.85 & 3.85 \\
\hline $\begin{array}{l}\text { Within } \\
\text { Groups }\end{array}$ & 112.46 & 113.83 & 694 & 694 & 0.16 & 0.16 & & & & & & \\
\hline Total & 531.72 & 530.89 & 695 & 695 & & & & & & & & \\
\hline
\end{tabular}

Tab. 16. ANOVA results; groups: the sum of discretionary accruals and country $(2019,2018)$

\begin{tabular}{|c|c|c|c|c|c|c|c|c|c|c|c|c|}
\hline \multirow{2}{*}{$\begin{array}{l}\text { Source of } \\
\text { Variation }\end{array}$} & \multicolumn{2}{|c|}{ SS } & \multicolumn{2}{|c|}{ df } & \multicolumn{2}{|c|}{ MS } & \multicolumn{2}{|c|}{$\mathrm{F}$} & \multicolumn{2}{|c|}{$\mathrm{P}$-value } & \multicolumn{2}{|c|}{ F crit. } \\
\hline & 2019 & 2018 & 2019 & 2018 & 2019 & 2018 & 2019 & 2018 & 2019 & 2018 & 2019 & 2018 \\
\hline Between & $1,075.49$ & $1,069.50$ & 1 & 1 & $1,075.49$ & $1,069.50$ & $1,570.69$ & $1,563.70$ & 2.243E- & 6.166E- & 3.85 & 3.85 \\
\hline $\begin{array}{l}\text { Within } \\
\text { Groups }\end{array}$ & 475.32 & 474.66 & 694 & 694 & 0.68 & 0.68 & & & & & & \\
\hline Total & $1,550.82$ & $1,544.16$ & 695 & 695 & & & & & & & & \\
\hline
\end{tabular}

\section{Discussion}

Current researches defined the importance of the role of earnings management practices in relation to the informative value of reported financial results (Ball and Shivakumar, 2005; Ugrin et al., 2017; Lo et al., 2017). The research shows that companies in the mining and quarrying sectors in V4 use earnings management techniques to manage profit. However, it is not possible to clearly determine in which direction they manage their profit more often. Different values were measured in the two observed periods. The existence of earnings management techniques was confirmed by using the modified Jones model. This model was chosen based on the comparison of the explanatory power calculated for the recommended models. Based on the recommended criteria described within the methodology part, this model has the highest explanatory power. Many studies also declare a higher explanatory power of this model (Feng and Qiangling, 2016; Nguyen and Nguyen, 2017; Li et al., 2019, Popp at al., 2018).

There are several studies focused on the relationship between the existence of earnings management practices and firm size. Only a few of them are focused on this topic within emerging countries or developing economies, as is the case of V4. Author Llukani (2013) confirmed the existence of earnings management practices in Albania, but there is no statistical relationship between the level of earnings management initiatives and company size. We focused mainly on the selected companies operating in the mining and quarrying sector. A statistically significant connection between the level of earnings management initiatives and company size in the years 2018 and 2019 was confirmed by using the one-way ANOVA test.

The contribution is also focused on the existence of the relationship between the earnings management practices and country of business operations. A statistically significant connection between the level of earnings management initiatives and country of business operations in the years 2018 and 2019 was confirmed by using the one-way ANOVA test. The average sum of the discretionary accruals was positive in Slovakia, as well as the 
Czech Republic in 2019. These companies used earnings management practices to increase their profit. On the other hand, the average sum of the discretionary accruals was negative in Poland and Hungary in 2019. Compared to the previous year 2018, only companies in the Czech Republic has a positive average sum of the discretionary accruals.

Based on the results, it can be stated that there are earnings management initiatives within companies operating in the mining and quarrying sector in V4. The level of the earnings management practices is not the same within countries. The level of the earnings management practices is not the same between companies with different sizes. According to the average sum of discretionary accruals, very large as well as large companies used earnings management practices to decrease their profit within the observed period. On the other hand, mediumsized companies used earnings management practices to increase their reported financial results. SMEs need to be supported financially at all levels (Olah et al., 2019). The most common form of financing is a bank loan. Banks provide a loan to a company based on its creditworthiness. The reason for using earnings management practices to increase the profit, which is significant for SMEs, may be the effort to report a higher profit in order to obtain a loan from the bank without any problems. This will also affect their innovation activity, innovation performance and competitiveness (Soltes and Gavurova, 2014).

\section{Conclusion}

The contribution is focused on the earnings management issue. The aim of the contribution was defined: Earnings management detection by using a model with the highest explanatory power, as well as verifying hypotheses about the existence of a statistically significant relationship between earnings management and country, as well as firm size within companies operating in the mining and quarrying sector in 2019 and 2018.

The explanatory power was tested by using four criteria within three selected earnings management models for detection, namely the modified Jones model, Industry model, and Kothari model. The modified Jones model was proclaimed as a model with the highest explanatory power. Based on the results, this model was used for earnings management detection.

Earnings management detection is determined by the sum of discretionary accruals. Almost $45 \%$ of companies used earnings management practices to increase their profit in 2019. The sum of these companies was lower compared to 2018. 180 out of 348 companies used earnings management practices to increase their profit in 2018. The remaining companies used earnings management practices to decrease their profit. Based on the results, the existence of earnings management within companies in the mining and quarrying sector was confirmed. The average sum of the discretionary accruals was -0.0005301 , the median was -0.0035237 , and the standard deviation was 0.0830728 in 2019 . The average sum of the discretionary accruals was 1.231402 , the median was 0,001016 , and the standard deviation was 0.104117 in 2018.

According to the results of the one-way ANOVA test, the statistically significant relation between earnings management initiatives and country, as well as firm size, was confirmed.

As it can be seen, many companies manage their reported financial numbers by earnings management techniques. The mining and quarrying sector is not excluded. Managing reported financial number to influence the image of the companies perceiving by the third parties. Based on the fact that companies use EM techniques in accounting legislation, it is not possible to prohibit their use. Therefore, it is important to know this fact.

In further studies, the authors plan to compare the explanatory power of other earnings management models, as well as earnings management detection in other business sectors.

\section{References}

Ball, R. (1972). Changes in accounting techniques and stock prices. Journal of Accounting Research, 10. DOI $10.2307 / 2489860$

Ball, R. and Shivakumar, L. (2005). Earnings Quality in U.K. Private Firms. Journal of Accounting and Economics, 3. DOI 10.2139/ssrn.335420

Behun, M., Gavurova, B., Tkacova, A. and Kotaskova, A. (2018). The impact of the manufacturing industry on the economic cycle of European Union countries. Journal of Competitiveness, 10(1), 23-39. DOI: 10.7441/joc.2018.01.02

Belas, J., Amoah, J., Petrakova, Z., Kliuchnikava, Y. and Bilan, Y. (2020). Selected Factors of SMEs Management in the Service Sector. Journal of Tourism and Services, 21(11). DOI 10.29036/jots.v11i21.215

Dechow, P. M. and Skinner, D.J. (2000). Earnings Management: Reconciling the Views of Accounting Academics, Practitioners, and Regulators. Available at SSRN: https://ssrn.com/abstract=218959. DOI 10.2139/ssrn.218959 
Dvorsky, J., Petrakova, Z.and Fialova, V. (2020a). Perception of Business Risks by Entrepreneurs According to Experience with the Business Failure. International Journal of Entrepreneurial Knowledge, 8 (1). DOI 10.37335/ijek.v8i1.104

Dvorsky, J., Petrakova, Z., Khan, K.A., Formanek, I. and Mikolas, Z. (2020b). Selected Aspects of Strategic Management in the Service Sector. Journal of Tourism and Services, 20 (11). DOI 10.29036/jots.v11i20.146

El Diri, M. (2018). Introduction to Earnings Management. US: Springer.

Feng, Y. and Qiangling, Z. (2017). Other comprehensive income and earnings management an empirical analysis based on modified Jones model. Conference: International Conference on Transformations and Innovations in Management. Shanghai, Peoples R China. DOI 10.2991/ictim-17.2017.68

Gavurova, B., Soltes, M. and Kovac, V. (2017). Application of Cluster Analysis in Process of Competitiveness Modelling of Slovak Republic Regions. Transformations in Business \& Economics, 16(3), 129-147.

Gunny, K.A. (2010). The Relation Between Earnings Management Using Real Activities Manipulation and Future Performance: Evidence from Meeting Earnings Benchmarks. Contemporary Accounting Research, 27(3). DOI $10.2139 /$ ssrn.816025

Hoglund, H. (2012). Detecting earnings management with neural networks. Expert Systems with Applications, 39(10). DOI 10.1016/j.eswa.2012.02.096

Hsieh, Y-T., Chen, T-K., Tseng, Y-J. and Lin, R-C. (2018). Top Management Team Characteristics and AccrualBased Earnings Management. International Journal of Accounting, 53(4). DOI 10.1016/j.intacc.2018.11.004

Cho, H.J., Choi, S. and Kwon, D.H. (2019). Employee tenure and earnings management through real activities manipulation. Asia-Pacific Journal of Accounting and Economics, will be published.

Khan, K.A., Çera, G. and Netek, V. (2019). Perception of the Selected Business Environment Aspects by Service Firms. Journal of Tourism and Services, 10(19). DOI 10.29036/jots.v10i19.115

Kim, S.H., Udawatte, P. and Yin, J. (2019). The Effects of Corporate Social Responsibility on Real and Accrualbased Earnings Management: Evidence from China. Autralian Accounting Review, 29(3). DOI 10.1111/auar.12235

Kliestik, T., Valaskova, K., Lazaroiu, G., Kovacova, M. and Vrbka, J. (2020). Remaining Financially Healthy and Competitive: The Role of Financial Predictors. Journal of Competitiveness, 12(1). DOI 10.7441/joc.2020.01.05

Kliestik, T., Valaskova, K., Nica, E., Kovacova, M. and Lazaroiu, G. (2020). Advanced methods of earnings management: monotonic trends and change-points under spotlight in the Visegrad countries. Oeconomia Copernicana, 11(2). DOI 10.24136/oc.2020.016

Lee, B. B. and Choi, B. (2002). Company size, auditor type and earnings management. Journal of Forensic Accounting, 15(3).

Li, CH., Pervaiz, K., Khan, M.A., Rehman, F.U. and Olah, J. (2019). On the Asymmetries of Sovereign Credit Rating Announcements and Financial Market Development in the European Region. Sustainability, 11(23). DOI $10.3390 /$ su11236636

Li, W., Ng, J., Tsang, A. and Urcan, O. (2019). Country-level institutions and management earnings forecasts. Journal of International Business Studies, 50(1). DOI 10.1057/s41267-018-0190-4

Llukani, T. (2013). Earnings management and firm size: an empirical analyze in Albanian market. European Scientific Journal, 9(16). DOI 10.19044/esj.2013.v9n16p\%p

Lo, K., Ramos, F. and Rogo, R. (2017). Earnings management and annual report readability. Journal of Accounting and Economics, 63(1). DOI 10.1016/j.jacceco.2016.09.002

Mendesa, C.A., Rodriguesb L.L. and Esteban, L. P. (2012). Evidence of earnings management using accruals as a measure of accounting discretion. Tékhne. Review of Applied Management Studies, 10(1). DOI $10.1016 / \mathrm{s} 1645-9911(12) 70002-6$

Metzker, Z. and Streimikis, J. (2020). CSR activities in the Czech SME segment. International Journal of Entrepreneurial Knowledge, 8(1). DOI 10.37335/ijek.v8i2.101

Mulford, Ch. W. and Comiskey, E. E. (2005). The Financial Numbers Game: Detecting Creative Accounting Practices. UK: Wiley.

Noyons, E. (2001). Bibliometric mapping of science in a science policy context. Scientometrics, 50. DOI 10.1023/A:1005694202977

Nguyen, A.H. and Nguyen, L.H. (2016). Modified Jones model and its reliability in detecting earnings management: a case of Vietnamese stock market. Conference: 3rd International Conference on Finance and Economics. Ho Chi Minh City, Vietnam. DOI 10.5539/ijef.v3n2p116

Olah, J., Kovacs, S., Virglerova, Z., Lakner, Z., Kovacova, M. and Popp, J. (2019). Analysis and Comparison of Economic and Financial Risk Sources in SMEs of the Visegrad Group and Serbia. Sustainability, 11(7). DOI $10.3390 / \mathrm{su} 11071853$

Pham, H. Y., Chung, R. Y. M., Roca, E. and Bao, B. H. (2019). Discretionary accruals: Signalling or earnings management in Australia? Accounting \& Finance, 59 (2). DOI 10.1111/acfi. 12275 
Popp, J., Olah, J., Machova, V. and Jachowicz, A. (2018). Private equity market of the Visegrad group. Ekonomicko-manazerske spektrum, 12(1). DOI 10.26552/ems.2018.1.1-15

Poradova, M. (2020). Negative consequences of creative accounting under the conditions of selected eastern European Economies. 56th International Scientific Conference on Economic and Social Development, Aveiro Portugal, 333-340.

Poradova, M. and Kollar, B. (2020). Creative accounting as a possible source of fraudulent behaviour in commercial corporations. 9th International Scientific Symposium, Osijek, Croatia, 1261-1271.

Rath, S. and Sun, L. (2008). The Development of Earnings Management Research. International Review of Business Research Papers, 4(2).

Ronen, J., Yaari, V. (2008). Earnings Management. US: Springer.

Roychowdhury, S. (2006). Earnings management through real activities manipulation. Journal of Accounting and Economics, 42(3). DOI 10.2139/ssrn.477941

Rozsa, Z., Formanek, I. and Manak, R. (2019). Determining the factors of the employees' intention to stay or leave in the Slovak's SMEs. International Journal of Entrepreneurial Knowledge, 7(2). DOI 10.37335/ijek.v7i2.94

Soltes, V. and Gavurova, B. (2014). Innovation policy as the main accelerator of increasing the competitiveness of small and medium-sized enterprises in Slovakia. Emerging Markets Queries in Finance and Business (EMQ 2013). Ed. Stefan, D., Comes, C.A. Munteanu, A., Nistor, P. Stefan, A.B. International Conference on Emerging Markets Queries in Finance and Business, Oct. 24-17, 2013, pp. 1478-1485. DOI: 10.1016/S22125671(14)00614-5.

Siregar, S. V.and Utama, S. (2008). Type of earnings management and the effect of ownership structure, firm size, and corporate-governance practices: Evidence from Indonesia. The International Journal of Accounting, 43(1). DOI 10.1016/j.intacc.2008.01.001

Sosnowski, T. (2018). Earnings management in the private equity divestment process on Warsaw Stock Exchange. Equilibrium. Quarterly Journal of Economics and Economic Policy, 13(4). DOI 10.24136/eq.2018.033

Svabova, L., Kramarova, K. and Durica, M. (2018). Prediction model of firm's financial distress. Ekonomickomanazerske spektrum, 12(1). DOI 10.26552/ems.2018.1.16-29

Ugrin, J. C., Mason, T. W. and Emley, A. (2017). Culturés consequence: The relationship between incomeincreasing earnings management and IAS/IFRS adoption across cultures. Advances in Accounting, 37. DOI 10.1016/j.adiac.2017.04.004

Valaskova, K., Gavurova, B., Durana, P. and Kovacova, M. (2020). Alter Ego Only Four Times? The Case Study of Business Profits in the Visegrad Group. E\&M Economics and Management, 23(3). DOI 10.15240/tul/001/2020-3-007

Vinczeova, M. and Kascakova, A. (2017). How do Slovak small and medium-sized enterprises make decision on sources of finance? Ekonomicko-manazerske spektrum, 11(2). DOI 10.26552/ems.2017.2.111-121

Watts, R. and Zimmerman, J.L. (1978). Towards a positive theory of the determination of accounting standards. The Accounting Review, 53 (1). 